\title{
Characterization of milk composition, coagulation properties, and cheese-making ability of goats reared in extensive farms
}

\author{
Pietro Paschino, ${ }^{1} \odot$ Giorgia Stocco, ${ }^{2} \odot$ Maria L. Dettori, ${ }^{1} \odot$ Michele Pazzola, ${ }^{1} \odot$ Maria L. Marongiu, ${ }^{1} \oplus$ \\ Carlo E. Pilo, ${ }^{1}$ Claudio Cipolat-Gotet, ${ }^{2 *}$ () and Giuseppe M. Vacca ${ }^{1}\left({ }^{\circ}\right.$ \\ ${ }^{1}$ Department of Veterinary Medicine, University of Sassari, 07100 Sassari, Italy \\ ${ }^{2}$ Department of Veterinary Science, University of Parma, 43126 Parma, Italy
}

\begin{abstract}
The aims of this study were to explore the variability of milk composition, coagulation properties, and cheese-making traits of the Sarda goat breed, and to investigate the effects of animal and farm factors, and the geographic area (Central-East vs. South-West) of an insular region of Italy, Sardinia. A total of 570 Sarda goats reared in 21 farms were milk-sampled during morning milking. Individual milk samples were analyzed for composition, traditional milk coagulation properties (MCP), modeled curd-firming over time parameters $\left(\mathrm{CF}_{\mathrm{t}}\right)$, and cheese-making traits (cheese yield, $\% \mathrm{CY}$; recovery of nutrients, \%REC; daily cheese yield, dCY). Farms were classified into 2 categories based on milk energy level (MEL; high or low), defined according to the average net energy of milk daily produced by the lactating goats. Milk yield and composition were analyzed using a mixed model including the fixed effects of MEL, geographic area, days in milk, and parity, and the random effect of farm within MEL and geographic area. Data about $\mathrm{MCP}, \mathrm{CF}_{\mathrm{t}}$, and the cheese-making process were analyzed using the same model, with the inclusion of the effects of animal and pendulum of the lactodynamograph instrument, allowing the measure of repeatability of these traits. Results showed that animal had greater influence on coagulation and cheesemaking traits compared with farm effect. Days in milk influenced milk composition, whose changes partly reflected the modifications of \% CY traits. Moreover, large differences were observed between primiparous and multiparous goats: primiparous goats produced less milk of better quality (higher fat, lower somatic cell and bacterial counts) and less cheese, but with higher recovery of fat and protein in the curd, compared with multiparous goats. The repeatability was very high, for both coagulation ( 84.0 to $98.8 \%$ ) and cheese-making
\end{abstract}

Received October 28, 2019.

Accepted March 9, 2020.

*Corresponding author: claudio.cipolatgotet@unipr.it traits (89.7 to $99.9 \%$ ). The effect of MEL was significant for daily productions of milk and cheese, coagulation time, and recovery of protein in the curd, which were better in high-MEL farms. As regards geographic area, milk composition and percentage cheese yield were superior in the Central-East area, whereas daily milk and cheese production and MCP were better in the SouthWest. This result was explainable by the phenomenon of crossbreeding Sarda goats with Maltese bucks, which occurred with greater intensity in the South-West than in the Central-East area of the island. The results provided by this study could be of great interest for the goat dairy sector. Indeed, the methods described in the present study could be applicable for other farming methods, goat breeds, and geographic areas. The collection of a wide range of phenotypes at individual animal level is fundamental for the characterization of local populations and can be used to guarantee breed conservation and the persistence of traditional farming systems, and to increase farmers' profit.

Key words: goat milk, coagulation, cheese-making, cheese yield

\section{INTRODUCTION}

Goat farming is an important sector of agriculture in many areas of the world, representing one of the main sources of livelihood (Lu and Miller, 2019). In some of these areas (northern Brazil, the Caribbean, and the Mediterranean and Middle Eastern regions of Europe), goat breeding is part of cultural heritage (Di Trana et al., 2015) and is based on the use of autochthonous breeds (Boyazoglu et al., 2005; Sponenberg et al., 2019), whose products are usually labeled with connotation of origin (e.g., Ibores, Chabichou du Poitou, Formaggella di Luinese). It is known that autochthonous goats perform better than cosmopolitan goat breeds in harsh environments, because of their greater physiological and anatomical adaptation (Silanikove, 2000). In this respect, it is strategic to improve knowledge and support the multipurpose local goat breeds and their 
genetic potential. Preservation of local breeds is fundamental, as they are essential for biodiversity (Di Trana et al., 2015) and can be a valuable source of economic income for dairy farmers. For example, a specific local breed can be closely related to a product (dairy or meat) with particular organoleptic characteristics (Di Trana et al., 2015); autochthonous breeds reared on the traditional extensive farming system can be associated with the production of functional foods (Čermák et al., 2013); and the traditional extensive farming system can be integrated with agro-tourism activity or with organic farming, which is still growing in the European market (Dubeuf, 2011). The high potential of local breeds worldwide is reported in several studies aimed at characterizing milk composition and cheese-making aptitude of indigenous compared with cosmopolitan goat breeds. Those studies have evidenced that, despite lower milk production, local breeds are characterized by higher contents of milk fat, protein, and total solids (Kouniba et al., 2007), curd firmness, cheese yield $(\% \mathbf{C Y})$, and recovery of nutrients in the curd (\%REC; Vacca et al., 2018a,b). The differences among breeds are explainable not only by different milk composition but also by genetic factors, in particular milk protein variants (Damián et al., 2008; Pazzola et al., 2014a).

Among autochthonous goat breeds reared in Sardinia, the Sarda is the most prevalent, with 29,000 animals recorded in the official herd book (FAO, 2014). The Sarda is characterized by skillful grazing behavior and is perfectly adapted to the semiarid environment of the island. In Sardinia, those goats are reared in traditional and extensive farming system methods, with free grazing pasture of the Mediterranean scrubland. The Sarda breed is also characterized by the excellent qualitative and technological characteristics of its milk and by very favorable genetic features (Pazzola et al., 2017). However, the repeated and unsupervised importation of dairy-specialized goat bucks (e.g., Saanen, MurcianoGrandina, Maltese) over the years, with the purpose of increasing milk production, has led to recombination of the original genetic characteristics of the Sarda breed. This phenomenon occurred with greater intensity in the South-West region of Sardinia (Vacca et al., 2016). At research level, only a few previous studies have examined milk production and quality, coagulation properties, and cheese-making ability from the Sarda goat breed, in most cases analyzing a low number of samples. Given that the characterization of local breeds' production (i.e., milk to cheese) represents one of the most important strategies for their conservation and a useful marketing instrument to raise public awareness about the importance of their preservation, we performed a large survey of the Sarda goat breed. The present study aimed to (1) quantify the contribution of animal and farm effects, within milk energy level and geographic area, on milk composition, coagulation properties, and cheese-making traits; (2) study the effect of high or low classification of milk energy production at farm level, defined according to the milk net energy daily yielded by the goats; (3) assess the effect of geographic area; and (4) characterize the effects of different stages of lactation and parity.

\section{MATERIALS AND METHODS}

\section{Farm Characteristics and Milk Sampling}

This study involved 570 Sarda goats reared in 21 farms located in the Central and South-East areas of Sardinia. Animals were selected among those officially registered in the flock books and enrolled in the milk recording system of provincial associations of goat breeders, on the basis of DIM and parity, to keep a good variability of the data set. Characteristics of sampled farms are reported in Table 1. Goat farming system included the extensive techniques described by Usai et al. (2006): mating was of natural type without estrus synchronization; kidding was concentrated from November to March; and adult goats were allowed to graze during the morning on natural pastures composed of the most common plants and bush of the Mediterranean area (Vacca et al., 2010). Farms were grouped as small ( $<100$ lactating goats), medium (100 to 200 lactating goats), or large (>200 lactating goats). As regards altitude, farms were grouped into those located in the plain $(<200 \mathrm{~m}$ above sea level), in the hills (200 to $500 \mathrm{~m}$ above sea level), or in the mountains $(>500 \mathrm{~m}$ above sea level). As reported in Table 1, the majority of farms in the Central-East of the island were located in the mountains ( 8 out of 11), and animals were handmilked (10 of 11), whereas in the South-West, farms were mostly located in the hills and plains (9 of 10), with mechanical milking (7 of 10). We also used the daily milk energy output (dMEO) of goats to define farms into 2 classes of milk energy levels (MEL). The net energy content of milk was calculated using the equation proposed by the NRC (2001):

$$
\begin{gathered}
\text { Net energy }(\mathrm{Mcal} / \mathrm{kg})=0.0929 \times \text { fat, } \%+0.0547 \\
\times \text { protein, } \%+0.0395 \times \text { lactose, } \%
\end{gathered}
$$

Then net energy (energy of $1 \mathrm{~kg}$ of milk) was converted to megajoules per kilogram and multiplied by the daily milk yield (dMY, $\mathrm{kg} / \mathrm{d})$ of each goat $(\mathrm{MJ} / \mathrm{d})$ to obtain the individual dMEO. Individual dMEO data were tested using ANOVA (GLM procedure, SAS version 9.4; SAS Institute Inc., Cary, NC) to obtain the least squares means (LSM) for the selected farms after cor- 
Table 1. Characteristics of sampled farms $(n=21)$

\begin{tabular}{|c|c|c|}
\hline \multirow[b]{2}{*}{ Item } & \multicolumn{2}{|c|}{ Geographic area } \\
\hline & Central-East & South-West \\
\hline Farms, no. & 11 & 10 \\
\hline Goats, no. & 194 & 376 \\
\hline \multicolumn{3}{|c|}{ Milk energy level, no. of farms } \\
\hline $\operatorname{High}(>3.91 \mathrm{MJ} / \mathrm{d})$ & 5 & 5 \\
\hline Low $(\leq 3.91 \mathrm{MJ} / \mathrm{d})$ & 6 & 5 \\
\hline \multicolumn{3}{|l|}{ Flock size, no. of farms } \\
\hline Small (<100 goats) & 2 & 3 \\
\hline Medium (100-200 goats) & 7 & 3 \\
\hline Large (>200 goats) & 2 & 4 \\
\hline \multicolumn{3}{|l|}{ Altitude, no. of farms } \\
\hline Plain $\left(<200 \mathrm{~m} \mathrm{asl}^{1}\right)$ & 2 & 4 \\
\hline Hill (200-500 m asl) & 1 & 5 \\
\hline Mountain (>500 m asl) & 8 & 1 \\
\hline \multicolumn{3}{|l|}{ Milking system, no. of farms } \\
\hline Mechanical & 1 & 7 \\
\hline Hand milked & 10 & 3 \\
\hline
\end{tabular}

recting for DIM and parity of the goats. After ranking the dMEO LSM of the 21 farms, they were categorized into high $(\mathrm{n}=10$, average $\mathrm{dMEO}=5.05 \mathrm{MJ} / \mathrm{d})$ or low MEL $(\mathrm{n}=11$, average dMEO $=2.91 \mathrm{MJ} / \mathrm{d})$ based on the median value $(3.91 \mathrm{MJ} / \mathrm{d})$.

\section{Analysis of Milk Composition}

Individual samples (200 mL/goat) were collected in sterile sample containers during the morning milking (1 sampling day for each farm) and stored at $4^{\circ} \mathrm{C}$ immediately after collection. In mechanical milking systems, milk was sampled from the recorder jar under each stall, and in the case of hand-milked systems, milk was collected from stainless steel graduated pails. Milk samples were analyzed within $24 \mathrm{~h}$ after collection. Clinical examinations were performed at the farms by veterinarians, and goats showing any clinical symptoms of mastitis (e.g., swollen, hot udder) or disease were not sampled. Milk fat, protein, lactose, total solids, $\mathrm{pH}$, and $\mathrm{NaCl}$ were calculated using a MilkoScan FT6000 milk analyzer (Foss Electric A/S, Hillerød, Denmark), calibrated according to FIL-IDF references (ISO-IDF, 2013, for fat, protein, lactose, $\mathrm{pH}$, and $\mathrm{NaCl}$; ISO-IDF, 2010, for total solids). Somatic cell counts were determined using a Fossomatic 5000 somatic cell counter (Foss Electric) and transformed into the logarithmic $\left[\log _{2}\left(\mathrm{SCC} \times 10^{-5}\right)+3\right]$ SCS, as reported by Shook (1993). Total bacterial count was measured using a BactoScan FC150 analyzer (Foss Electric) and transformed into the logarithmic bacterial count $\left[\mathbf{L B C}=\log _{10}\right.$ (total bacterial count/1,000)] according to ISO-IDF (2004). Milk yield (MY) was recorded for each goat using the recorder jar in the case of mechanical milking and the stainless steel graduated pails in the case of manual milking. Daily milk yield was then calculated as the total yield of morning plus evening milkings of the same day of sample collection.

\section{The 9-mL Milk Cheese-Making Assessment}

The 9-mL milk cheese-making assessment proposed and described in detail by Cipolat-Gotet et al. (2016a) was used to obtain traditional milk coagulation properties $(\mathbf{M C P}), \% \mathrm{CY}$, and \%REC traits. The procedure was performed in duplicate per each individual milk sample (2 replicates of $9 \mathrm{~mL}$ ), for a total of 1,140 observations. This procedure allowed recording of the single-point traditional MCP [rennet coagulation time (RCT, min), defined as the time interval between rennet addition and gelation; curd-firming time $\left(\mathbf{k}_{\mathbf{2 0}}\right.$, $\min )$, the time between gelation and the attainment of curd firmness of $20 \mathrm{~mm}$; and curd firmness at 30 min after rennet addition $\left.\left(\mathbf{a}_{\mathbf{3 0}}, \mathbf{m m}\right)\right]$; and $\% \mathrm{CY}$ traits, $\mathrm{FCY}_{\mathrm{CURD}}, \mathrm{\% CY}_{\text {SOLIDS }}$, and $\% \mathrm{CY}_{\text {WATER }}$, calculated as the ratio of the weights of fresh curd, curd DM, and water retained in curd, respectively, to the weight of the milk processed, multiplied by 100 . The recorded nutrient recovery traits were: $\% \mathbf{R E C}_{\text {PROTEIN }}, \mathbf{O R E C}_{\mathrm{FAT}}$, and $\% \mathbf{R E C} \mathbf{C}_{\text {SOLIDS }}$, calculated as the ratio of the weight of the curd components (protein, fat, and total solids, respectively) to the weight of the same milk component, multiplied by 100. Daily cheese yield (dCY) traits $\left(\mathbf{d} \mathbf{C} \mathbf{Y}_{\text {CURD }}, \mathbf{d C Y}_{\text {SOLIDS }}\right.$, and $\left.\mathbf{d} \mathbf{C} \mathbf{Y}_{\text {WATER }}, \mathrm{kg} / \mathrm{d}\right)$ were calculated by multiplying \% CY (\% $\mathrm{CY}_{\mathrm{CURD}}, \% \mathrm{CY}_{\text {SOLIDS }}$, and $\% \mathrm{CY}_{\text {WATER}}$, respectively) by the individual dMY of goats.

\section{Modeling of Curd Firmness}

During the lactodynamographic analysis, the Formagraph recorded every $15 \mathrm{~s}$ the width $(\mathrm{mm})$ of the oscillatory graph of the pendula immerged in each milk sample. Consequently, 120 curd firmness measures were recorded for each milk sample during 30-min analysis. The possibility of exploiting all these values allowed us to appropriately model the evolution of the coagulation process of each sample and to make the lactodynamographic analysis more informative. We used a 3-parameter model (Bittante, 2011) as follows:

$$
\mathrm{CF}_{\mathrm{t}}=\mathrm{CF}_{\mathrm{P}} \times\left(1-\mathrm{e}^{-\mathrm{k}_{\mathrm{CF}}\left(\mathrm{t}-\mathrm{RCT}_{\mathrm{eq}}\right)}\right)
$$

where $\mathrm{CF}_{\mathrm{t}}$ is curd firmness at time $\mathrm{t}(\mathrm{mm}) ; \mathrm{CF}_{\mathrm{P}}$ is the asymptotical potential value of $\mathrm{CF}$ at an infinite time in absence of syneresis $(\mathrm{mm}) ; \mathrm{k}_{\mathrm{CF}}$ is the curd-firming 
instant rate constant $(\% / \mathrm{min})$; and $\mathrm{RCT}_{\mathrm{eq}}$ (min) is $\mathrm{RCT}$ estimated by the $\mathrm{CF}_{\mathrm{t}}$ equation on the basis of all data points.

\section{Statistical Analysis}

For each milk sample, a curvilinear regression was fit to the $120 \mathrm{CF}_{\mathrm{t}}$ values available for each sample using the nonlinear procedure (PROC NLIN) of SAS (SAS Institute Inc.). The parameters of each individual equation were estimated employing the Marquardt iterative method (350 iterations and $10^{-5}$ level of convergence).

Traditional MCP, $\mathrm{CF}_{\mathrm{t}}$ parameters, and cheese-making traits were analyzed using the MIXED procedure of SAS, according to the following model:

$$
\begin{aligned}
& \mathrm{y}_{\text {mnopqrst }}=\mu+ \text { DIM }_{\mathrm{m}}+\text { Parity }_{\mathrm{n}}+\text { Area }_{\mathrm{o}}+\text { MEL }_{\mathrm{p}} \\
&+ \text { Farm }_{\left(\mathrm{MEL}_{\mathrm{p}}, \text { Area }_{\mathrm{o}}\right)_{\mathrm{q}}+\text { Animal }_{\mathrm{r}}} \\
&+ \text { Pendulum }_{\mathrm{s}}+\mathrm{e}_{\text {mnopqrst }},
\end{aligned}
$$

where $\mathrm{y}_{\text {mnopqrst }}$ is the observed trait $\left(\mathrm{RCT}, \mathrm{k}_{20}, \mathrm{a}_{30}\right.$; $\mathrm{RCT}_{\mathrm{eq}}, \mathrm{k}_{\mathrm{CF}}, \mathrm{CF}_{\mathrm{P}} ; \% \mathrm{CY}, \% \mathrm{REC}$, and dCY traits); $\mu$ is the overall population mean; DIM $_{m}$ is the fixed effect of the mth class of days in milk $[\mathrm{m}=1$ to 7 ; class $1: \leq 70$ d (126 samples); class 2: 71 to 100 d (242 samples); class 3: 101 to $130 \mathrm{~d}$ (121 samples); class 4: 131 to 160 d (128 samples); class 5: 161 to 190 d (186 samples) class 6: 191 to $220 \mathrm{~d}$ (164 samples); class 7: $>220$ d (82 samples)]; Parity ${ }_{\mathrm{n}}$ is the fixed effect of the nth parity [n $=1$ to 5 ; class 1 : first parity (186 samples); class 2 : second (270 samples); class 3: third (226 samples); class 4: fourth (162 samples); class 5 : $\geq$ fifth (296 samples)]; Area $_{\mathrm{o}}$ is the fixed effect of the oth class of area $[0=1$ to 2; class 1: Central-East; class 2: South-West)]; $\mathrm{MEL}_{\mathrm{p}}$ is the fixed effect of the pth class of milk energy level [p $=1$ to 2; class 1: high MEL (>3.91 MJ/d); class 2: low MEL $(\leq 3.91 \mathrm{MJ} / \mathrm{d})]$; Farm $\left(\mathrm{MEL}_{\mathrm{p}} \text {, Area }\right)_{\mathrm{q}}$ is the random effect of the qth farm ( $q=1$ to 21$)$ within the pth class of MEL and the oth class of area; Animal $_{\mathrm{r}}$ is the random effect of the rth animal $(\mathrm{r}=1$ to 570); Pendu$\operatorname{lum}_{\mathrm{s}}$ is the random effect of the sth pendulum of the lactodynamograph instrument ( $\mathrm{s}=1$ to 8$)$; and $\mathrm{e}_{\text {mnopqrst }}$ is the random residual $\sim N\left(0, \sigma_{\mathrm{e}}^{2}\right)$, where $\sigma_{\mathrm{e}}^{2}$ is the residual variance.

Milk composition was analyzed using a modification of model [M1], without inclusion of the random effect of animal and pendulum of the instrument, named model [M2].

Orthogonal polynomial contrasts were estimated between the LSM of classes of DIM (linear, quadratic, and cubic relationships) to observe possible significant patterns in the tested milk traits. The 4 degrees of freedom of parity effect were used to test the following contrasts: (1) first versus second; (2) first versus second or greater; (3) second versus third or greater; and (4) third versus fourth or greater.

Repeatability (expressed in percentage) for MCP, $\mathrm{CF}_{\mathrm{t}}$ parameters, and cheese-making traits was calculated as the ratio of the sum of the variances of the random effects [Farm(MEL, Area), animal, pendulum] to the sum of the variances of the random effects and the random residual.

\section{RESULTS}

Descriptive statistics of milk yield, composition, traditional coagulation properties (MCP), modeled curdfirming over time $\left(\mathbf{C F}_{\mathrm{t}}\right)$ parameters, and cheese-making traits of individual goat milk samples are reported in Table 2.

We performed ANOVA for fixed effects, variance of random effects, and repeatability of $\mathrm{MCP}, \mathrm{CF}_{\mathrm{t}}$ parameters, and cheese-making traits, as reported in Table 3. As regards the random effects, farm variance was generally lower than 50\%, excluding LBC. Animal variance was larger than that of farm on coagulation (from 47 to $85 \%$ ), \%CY (except for $\% \mathrm{CY}_{\text {WATER }}$ ), \%REC (from 68 to $75 \%$ ), and dCY traits (from 61 to $73 \%$ ). Percentages of repeatability were between $84.0\left(\mathrm{a}_{30}\right)$ and $99.9 \%$ $\left(\% \mathrm{CY}_{\text {SOLIDS }}\right)$.

Table 4 reports LSM of milk and coagulation traits according to milk energy level and geographic area. The effect of MEL was significant, with higher daily productions of milk and cheese, better coagulation time $\mathrm{RCT}_{\text {eq }}$, and greater $\% \mathrm{REC}_{\text {PRoteIn }}$ from goats reared in high-MEL farms. With regard to the effect of the geographic area, goats reared in the South-West area showed higher dMY and $\mathrm{NaCl}$, and lower concentrations of milk fat, protein, lactose, and total solids. The $k_{20}$ was shorter and $a_{30}$ was higher in milk from goats reared in the South-West area.

Figure 1 summarizes the effect of DIM. Daily milk yield and daily cheese yield decreased across DIM (Figure 1a); fat and protein contents had a tendency to increase, and lactose decreased, all with cubic trends (Figure $1 \mathrm{~b}$ ); $\mathrm{NaCl}$ increased with a cubic trend, with a peak between 161 and $190 \mathrm{~d}$ (Figure 1d). Coagulation traits were not affected by DIM, except for $\mathrm{CF}_{\mathrm{P}}$, which showed a quadratic trend, with the lowest values between 131 and $160 \mathrm{~d}$ (data not shown); cheese yield traits changed across lactation with cubic trends (Figure 1e); \%REC traits were not affected by DIM, except $\% \mathrm{REC}_{\text {SOLIDS }}$, with the lowest value between 101 and $130 \mathrm{~d}$ (data not shown).

The effect of parity and orthogonal contrasts are reported in Table 5. Goats at first parity had lower milk 
Table 2. Descriptive statistics of milk yield, composition, traditional coagulation properties (MCP), and modeled curd-firming over time $\left(\mathrm{CF}_{\mathrm{t}}\right)$ parameters and cheese-making traits of individual goat milk samples

\begin{tabular}{|c|c|c|c|c|}
\hline \multirow[b]{2}{*}{ Item } & \multirow[b]{2}{*}{ Mean } & \multirow[b]{2}{*}{$\mathrm{SD}$} & \multicolumn{2}{|c|}{ Percentile $^{1}$} \\
\hline & & & P5 & P95 \\
\hline $\mathrm{MY},{ }^{2} \mathrm{~kg} / \mathrm{d}$ & 1.10 & 0.51 & 0.42 & 2.20 \\
\hline \multicolumn{5}{|l|}{ Milk composition } \\
\hline Fat, \% & 5.28 & 1.22 & 3.41 & 7.47 \\
\hline Protein, $\%$ & 3.93 & 0.48 & 3.19 & 4.81 \\
\hline Lactose, \% & 4.61 & 0.27 & 4.15 & 5.04 \\
\hline $\mathrm{TS}, \%$ & 14.83 & 1.53 & 12.50 & 17.50 \\
\hline $\mathrm{NaCl}$ & 245 & 50 & 170 & 327 \\
\hline $\mathrm{pH}$ & 6.72 & 0.10 & 6.55 & 6.88 \\
\hline $\mathrm{SCS}^{3}$ & 6.63 & 1.80 & 3.63 & 9.49 \\
\hline $\mathrm{LBC}^{4}$ & 1.75 & 0.87 & 0.30 & 3.27 \\
\hline \multicolumn{5}{|l|}{ Traditional $\mathrm{MCP}^{5}$} \\
\hline $\mathrm{RCT}, \min$ & 13.37 & 4.55 & 8.15 & 23.30 \\
\hline $\mathrm{k}_{20}, \min$ & 3.61 & 1.19 & 2.15 & 6.30 \\
\hline $\mathrm{a}_{30}, \mathrm{~mm}$ & 37.14 & 9.90 & 18.42 & 51.04 \\
\hline \multicolumn{5}{|c|}{ Modeled $\mathrm{CF}_{\mathrm{t}}$ parameters ${ }^{6}$} \\
\hline $\mathrm{RCT}_{\mathrm{eq}}, \min$ & 13.60 & 3.90 & 8.88 & 22.07 \\
\hline $\mathrm{k}_{\mathrm{CF}}, \% / \mathrm{min}$ & 21.21 & 6.92 & 10.22 & 33.67 \\
\hline $\mathrm{CF}_{\mathrm{P}}, \mathrm{mm}$ & 42.22 & 10.25 & 25.12 & 58.52 \\
\hline \multicolumn{5}{|c|}{ Cheese yields (CY), \% } \\
\hline$\% \mathrm{CY}_{\mathrm{CURD}}$ & 19.04 & 3.12 & 14.57 & 24.68 \\
\hline$\% \mathrm{CY}_{\text {SOLIDS }}$ & 9.09 & 1.56 & 6.77 & 11.64 \\
\hline$\% \mathrm{CY}$ WATER & 9.78 & 2.08 & 6.86 & 13.96 \\
\hline \multicolumn{5}{|c|}{ Nutrient recovery (REC), \% } \\
\hline$\% \mathrm{REC}_{\mathrm{FAT}}$ & 85.34 & 4.34 & 76.89 & 91.67 \\
\hline$\%$ REC $_{\text {PROTEIN }}$ & 81.19 & 2.71 & 76.25 & 85.25 \\
\hline$\% \mathrm{REC}_{\text {SOLIDS }}$ & 60.43 & 4.28 & 52.76 & 67.01 \\
\hline \multicolumn{5}{|c|}{ Daily production traits, ${ }^{7} \mathrm{~kg} / \mathrm{d}$} \\
\hline $\mathrm{dCY}_{\mathrm{CURD}}$ & 0.208 & 0.096 & 0.079 & 0.392 \\
\hline $\mathrm{dCY}_{\text {SOLIDS }}$ & 0.098 & 0.043 & 0.041 & 0.182 \\
\hline $\mathrm{dCY}_{\text {WATER }}$ & 0.107 & 0.050 & 0.039 & 0.206 \\
\hline
\end{tabular}

${ }^{1} \mathrm{P} 5$ and $\mathrm{P} 95=5$ th and 95th percentiles, which indicate the upper and lower 5\% limits in the 2-tailed distribution of data.

${ }^{2} \mathrm{MY}=$ milk yield.

${ }^{3} \mathrm{SCS}=\log _{2}\left(\mathrm{SCC} \times 10^{-5}\right)+3$.

${ }^{4} \mathrm{LBC}=$ logarithmic bacterial count: $\log _{10}($ total bacterial count $/ 1,000)$.

${ }^{5} \mathrm{RCT}=$ measured rennet gelation time; $\mathrm{k}_{20}=$ time interval between gelation and attainment of curd firmness of $20 \mathrm{~mm} ; \mathrm{a}_{30}=$ curd firmness $30 \mathrm{~min}$ after rennet addition.

${ }^{6} \mathrm{RCT}_{\mathrm{eq}}=$ rennet coagulation time estimated by $\mathrm{CF}_{\mathrm{t}}$ modeling; $\mathrm{k}_{\mathrm{CF}}=$ curd firming instant rate constant; $\mathrm{CF}_{\mathrm{P}}$ = asymptotic potential curd firmness.

${ }^{7} \mathrm{dCY}=$ daily cheese yield.

production compared with multiparous goats. Goats at second parity had slightly lower milk production compared with goats at third and higher parities. Compared with older goats, milk from younger ones was characterized by higher fat, lactose, and total solids contents, and lower $\mathrm{NaCl}$, SCS, and LBC. The LBC was lower in goats at first and second parities.

\section{DISCUSSION}

\section{Effects of Animal and Farm, and Repeatability of Coagulation and Cheese-Making Traits}

To the best of our knowledge, this is the first study presenting a detailed description of dairy production performance (from milk to cheese) of a local goat (Sarda) breed, so we could only partially compare our results with those available from the literature. On average, MY and percentages of milk fat and protein were similar to data reported by Pazzola et al. (2017), whereas curd firmness values reported in this study are slightly lower, and $\% \mathrm{CY}_{\mathrm{CURD}}$ is higher.

It is acknowledged that a variable proportion of the animal effect on coagulation traits is due to genetic aspects (i.e., casein polymorphism, whey protein genes; Damián et al., 2008; Dettori et al., 2015a) and composition of milk (Vacca et al., 2018a). Large amounts of $\alpha_{\mathrm{S1}^{-}}$ casein (Clark and Sherbon, 2000) are related to delayed coagulation times but higher curd firmness values, and overall high milk protein and casein contents are associ- 
Paschino et al.: TECHNOLOGICAL QUALITY OF SARDA GOAT MILK

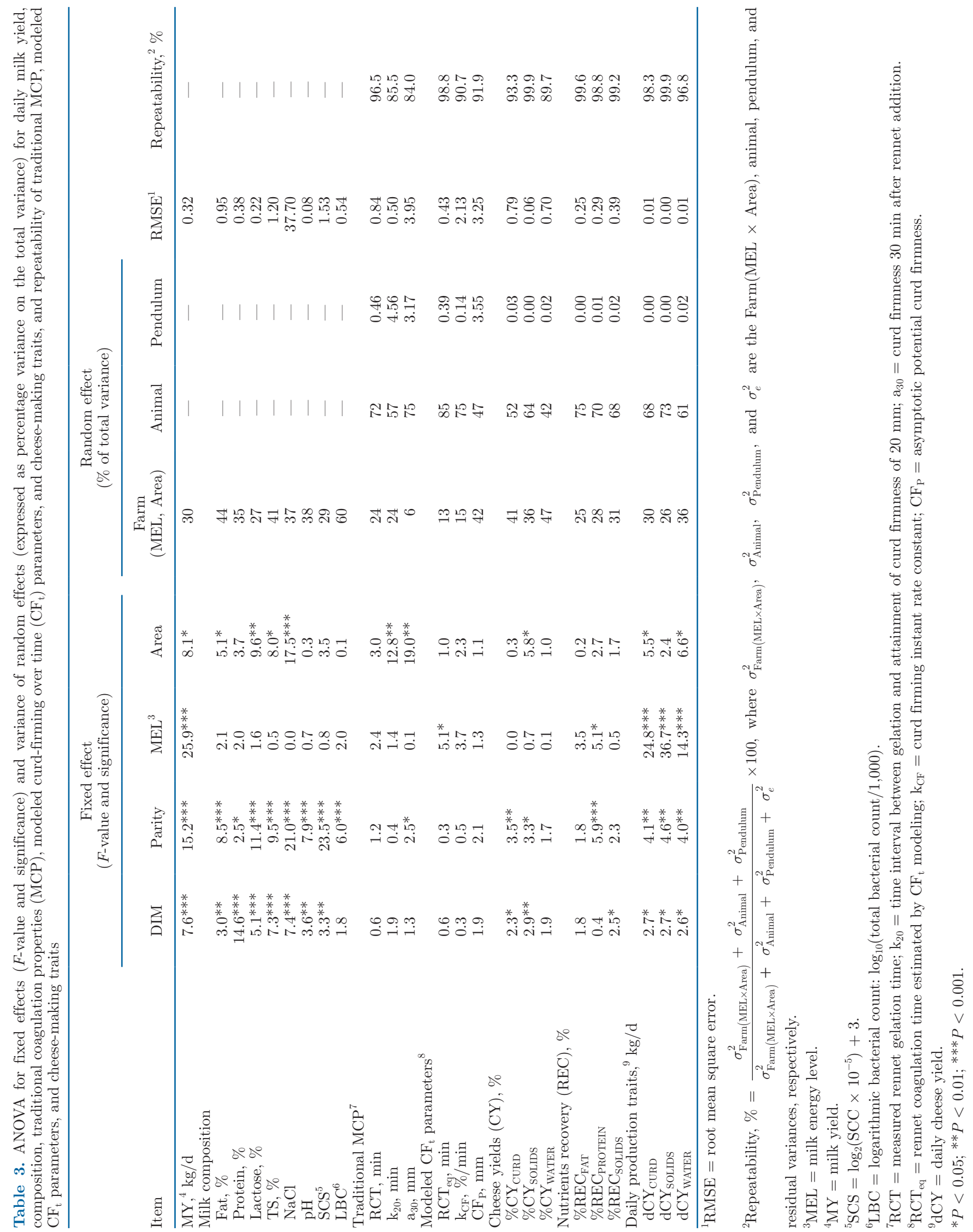


Table 4. Least squares means of milk energy level (MEL) and geographic area for milk yield, composition, traditional coagulation properties $(\mathrm{MCP})$, modeled curd-firming over time $\left(\mathrm{CF}_{t}\right)$ parameters, and cheesemaking traits of individual goat milk samples

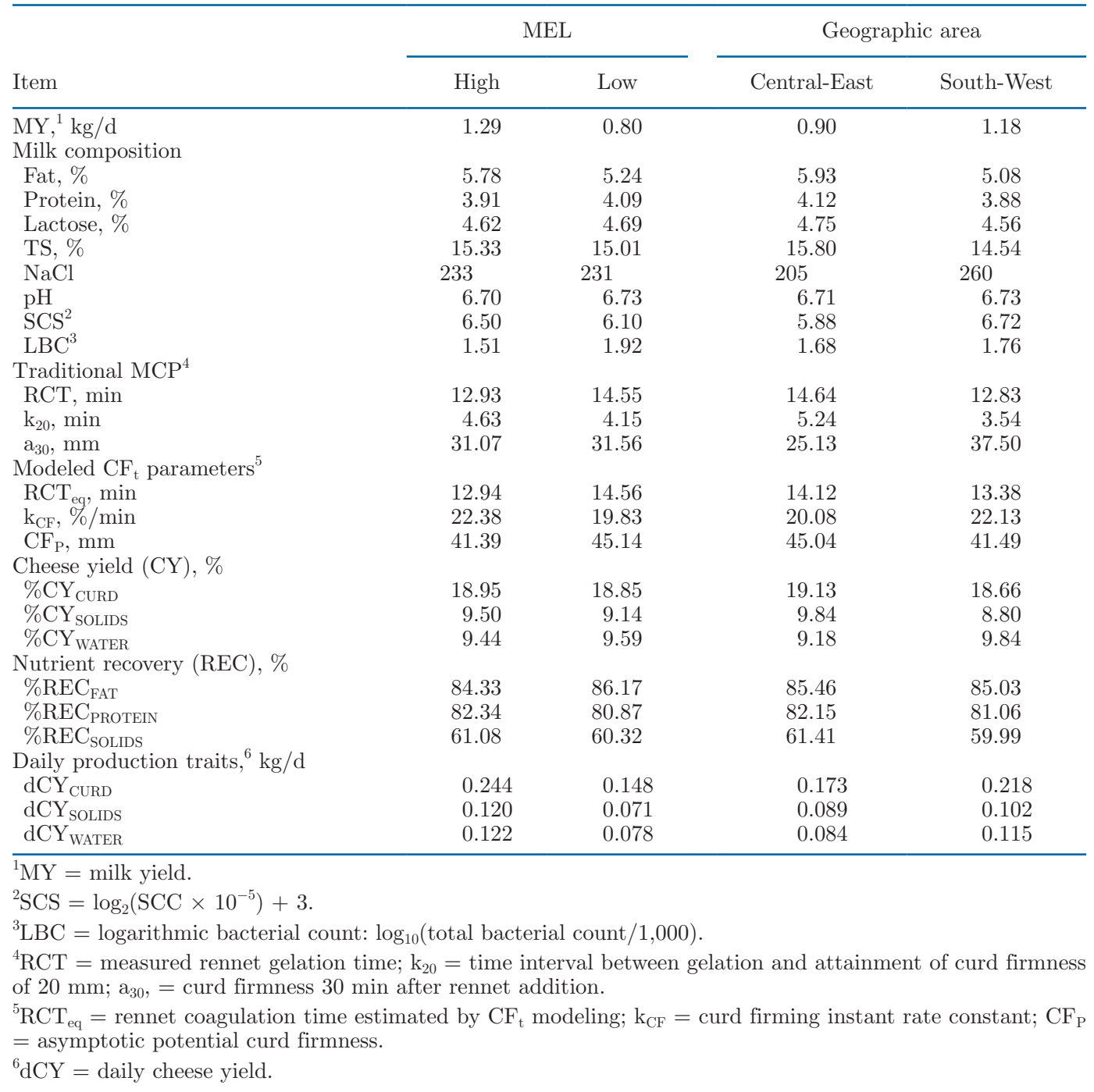

ated with high \% CY and \% REC traits (Pazzola et al., 2019). Moreover, high milk fat is generally associated with better coagulation properties (Clark and Sherbon, 2000) and higher \%CY (Guo et al., 2004), \%REC traits, and daily cheese production (Pazzola et al., 2019). The animal effect on the total variability of milk and cheese traits supports that Sarda goats are characterized by a large genetic component (casein polymorphism), even larger than that of other goat breeds (Moioli et al., 2007). However, this aspect needs to be better explored if the preservation of the Sarda breed is considered.

With regard to repeatability, we compared our results with some data from bovines and ovines, as this is the first study reporting individual repeatability values for coagulation traits in goat milk. Bovine MCP are characterized by lower instrumental repeatability and reproducibility than milk composition traits (Tyrisevä et al., 2003; Dal Zotto et al., 2008), especially for those properties recorded in the last part of the lactodynamographic analysis (curd firmness at $60 \mathrm{~min}$, potential curd firmness, and syneresis rate). However, although MCP are highly influenced by instrument (mechanical or optical devices; Cipolat-Gotet et al., 2012) and conditions of analysis (type and concentration of rennet, milk temperature, and acidification; Nájera et al., 2003), the individual cow repeatability can be considered high (Bittante et al., 2012). Repeatability values of MCP from sheep are almost similar to those of bovine milk (Ferragina et al., 2017). In this study, the individual goat repeatability of RCT and $\mathrm{k}_{20}$ was higher than that of dairy cows, but for $\mathrm{a}_{30}$ it was lower (Stocco et al., 2017). Moreover, among species (Ferragina et 
al., 2017; Stocco et al., 2017) the repeatability of modeled $\mathrm{CF}_{\mathrm{t}}$ parameters is generally higher compared with that of traditional MCP, and in goats this difference was even greater. The very different coagulation patterns among species provided by the modeling of data obtained during the lactodynamographic test (Pazzola et al., 2018) could explain why repeatability values of these traits are also different: in sheep and goat milk maximum consistency of the curd is usually attained within $30 \mathrm{~min}$ of rennet addition, and after $30 \mathrm{~min}$ in
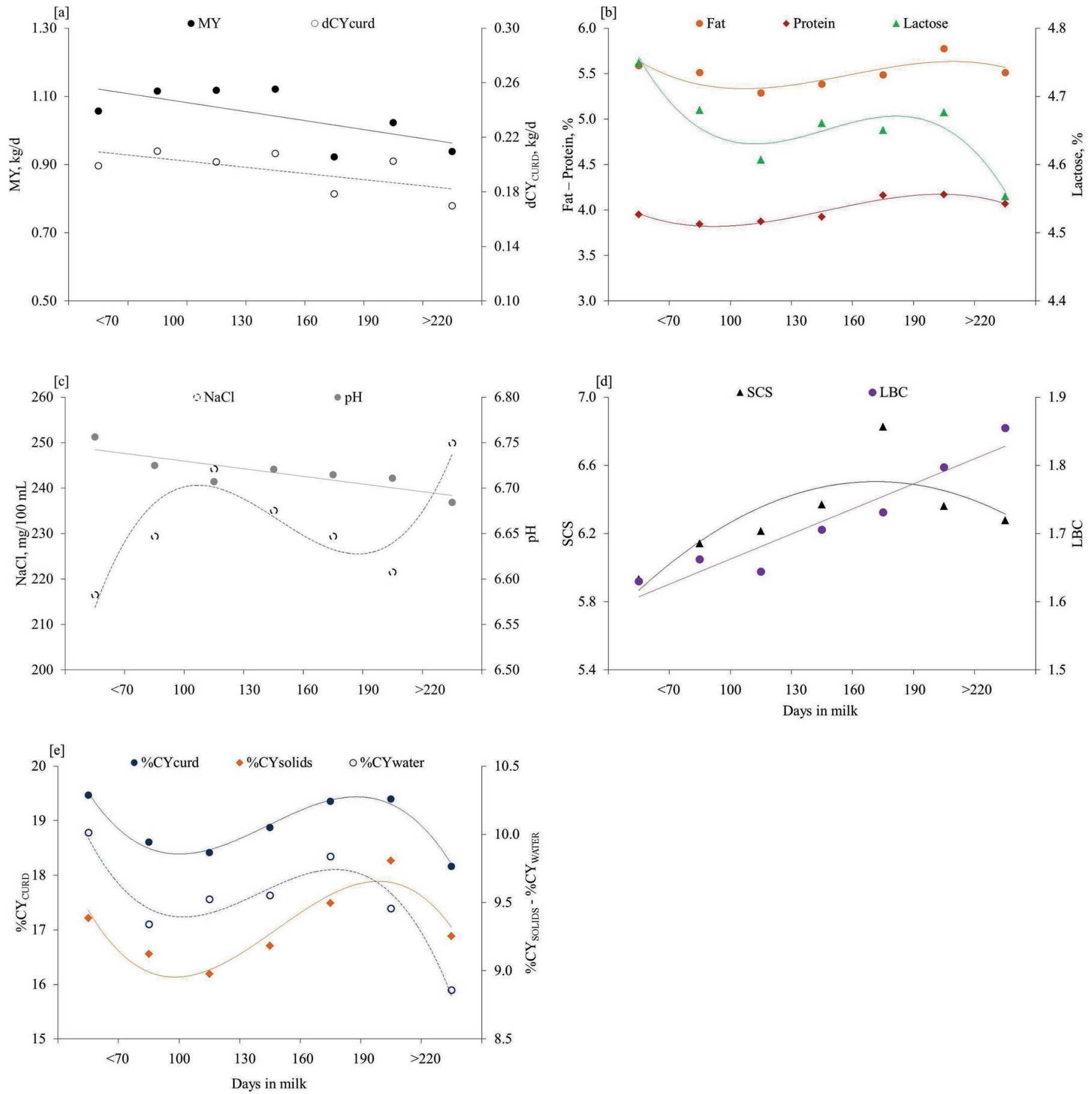

Figure 1. Effects of DIM on (a) milk yield (MY) and daily cheese yield (dCY); (b) fat, protein, and lactose; (c) NaCl and pH; (d) SCS and logarithmic bacterial count (LBC); and (e) cheese yield traits (\%CY) of Sarda goats. 
cows. Consequently, $\mathrm{a}_{30}$ values are usually measured in the ascending phase of the curd-firming curve when bovine milk is analyzed, and in the descending phase when milk from small ruminants is tested. The high individual repeatability of cheese-making traits was expected, but it was even higher compared with that reported in Vacca et al. (2018a) for 6 breeds of goats. These results evidenced that the 9-mL milk cheesemaking assessment can be a powerful tool, particularly compelling for the characterization of the cheese-making ability of milk from local populations. Indeed, it allows the rapid, cheap, and partly automated analysis of several samples per day, using instruments commonly used in many laboratories for the evaluation of MCP.
The concomitant use of the modeling of the renneting data allows a more detailed description of the coagulation process. All these phenotypes are of interest for the dairy sector, and the possibility of collecting them at the individual level could speed the improvement and favor the conservation of the genetic resources of local goat populations.

\section{Effect of Milk Energy Level}

To our knowledge, no previous studies have investigated the effect of milk energy at farm level on the production, composition, coagulation traits, and cheesemaking ability of Sarda goat milk. The average values

Table 5. Least squares means of classes of parity and their orthogonal contrasts ( $F$-value and significance) for milk yield, composition, traditional coagulation properties $(\mathrm{MCP})$, modeled curd-firming over time $\left(\mathrm{CF}_{\mathrm{t}}\right)$ parameters, and cheese-making traits of individual goat milk samples

\begin{tabular}{|c|c|c|c|c|c|c|c|c|c|}
\hline Item & \multicolumn{5}{|c|}{ Parity, LSM } & \multicolumn{4}{|c|}{ Contrast, $F$-value and significance } \\
\hline Fat, $\%$ & 5.82 & 5.57 & 5.53 & 5.41 & 5.21 & $6.9^{* *}$ & $20.9^{* * *}$ & $5.5^{*}$ & $6.3^{*}$ \\
\hline Protein, \% & 3.99 & 4.00 & 3.97 & 4.07 & 3.95 & 0.0 & 0.0 & 0.0 & 1.4 \\
\hline $\mathrm{NaCl}$ & 213 & 224 & 237 & 239 & 249 & $7.5^{* *}$ & $49.5^{* * *}$ & $33.6^{* * *}$ & $4.9 *$ \\
\hline $\mathrm{pH}$ & 6.73 & 6.74 & 6.72 & 6.71 & 6.69 & 1.1 & 3.4 & $20.8^{* * *}$ & $5.5^{*}$ \\
\hline $\mathrm{SCS}^{2}$ & 5.51 & 5.90 & 6.61 & 6.50 & 7.00 & $6.2^{*}$ & $51.6^{* * *}$ & $41.2^{* * *}$ & 1.2 \\
\hline $\mathrm{LBC}^{3}$ & 1.59 & 1.62 & 1.81 & 1.75 & 1.81 & 0.3 & $10.4^{* *}$ & $14.4^{* * *}$ & 0.4 \\
\hline \multicolumn{10}{|l|}{ Traditional $\mathrm{MCP}^{4}$} \\
\hline $\mathrm{RCT}, \min$ & 13.13 & 13.35 & 14.00 & 14.38 & 13.83 & 0.2 & 2.3 & 2.6 & 0.1 \\
\hline $\mathrm{k}_{20}, \min$ & 4.38 & 4.35 & 4.41 & 4.27 & 4.53 & 0.0 & 0.0 & 0.2 & 0.0 \\
\hline \multicolumn{10}{|l|}{ Modeled $\mathrm{CF}_{\mathrm{t}}$ parameters ${ }^{5}$} \\
\hline$\% \mathrm{CY}_{\mathrm{CURD}}$ & 19.34 & 19.15 & 18.95 & 18.91 & 18.15 & 0.4 & 3.6 & 3.3 & 2.2 \\
\hline$\% \mathrm{CY}_{\text {SOLIDS }}$ & 9.60 & 9.43 & 9.29 & 9.34 & 8.93 & 0.9 & $5.0^{*}$ & 2.9 & 1.0 \\
\hline$\% \mathrm{CY}_{\text {WATER }}$ & 9.63 & 9.62 & 9.51 & 9.63 & 9.16 & 0.0 & 0.6 & 1.1 & 0.4 \\
\hline \multicolumn{10}{|l|}{ Nutrient recovery (REC), \% } \\
\hline$\% \mathrm{REC}_{\mathrm{FAT}}$ & 85.89 & 85.76 & 84.86 & 85.07 & 84.66 & 0.1 & 3.0 & $4.5^{*}$ & 0.0 \\
\hline$\%$ REC $_{\text {PROTEIN }}$ & 82.44 & 82.07 & 81.43 & 81.03 & 81.04 & 1.4 & $13.8^{* * *}$ & $12.2^{* * *}$ & 2.0 \\
\hline$\% \mathrm{REC}_{\text {SOLIDS }}$ & 61.34 & 60.98 & 60.84 & 60.51 & 59.82 & 0.5 & 3.3 & 2.1 & 2.4 \\
\hline \multicolumn{10}{|l|}{ Daily production traits, ${ }^{6} \mathrm{~kg} / \mathrm{d}$} \\
\hline $\mathrm{dCY}_{\mathrm{CURD}}$ & 0.173 & 0.194 & 0.210 & 0.206 & 0.196 & $5.3^{*}$ & $12.4^{* * *}$ & 1.8 & 1.3 \\
\hline $\mathrm{dCY}_{\text {SOLIDS }}$ & 0.084 & 0.095 & 0.102 & 0.101 & 0.097 & $6.8^{* *}$ & $15.6^{* * *}$ & 2.3 & 0.6 \\
\hline $\mathrm{dCY} Y_{\text {WATER }}$ & 0.087 & 0.099 & 0.106 & 0.107 & 0.100 & $5.5^{*}$ & $12.8^{* * *}$ & 2.0 & 0.4 \\
\hline
\end{tabular}

${ }^{1} \mathrm{MY}=$ milk yield.

${ }^{2} \mathrm{SCS}=\log _{2}\left(\mathrm{SCC} \times 10^{-5}\right)+3$.

${ }^{3} \mathrm{LBC}=$ logarithmic bacterial count: $\log _{10}($ total bacterial count/1,000).

${ }^{4} \mathrm{RCT}=$ measured rennet gelation time; $\mathrm{k}_{20}=$ time interval between gelation and attainment of curd firmness of $20 \mathrm{~mm} ; \mathrm{a}_{30},=$ curd firmness 30 min after rennet addition.

${ }^{5} \mathrm{RCT}_{\mathrm{eq}}=$ rennet coagulation time estimated by $\mathrm{CF}_{\mathrm{t}}$ modeling; $\mathrm{k}_{\mathrm{CF}}=$ curd firming instant rate constant; $\mathrm{CF}_{\mathrm{P}}=$ asymptotic potential curd firmness.

${ }^{6} \mathrm{dCY}=$ daily cheese yield.

${ }^{*} P<0.05$; ${ }^{* *} P<0.01 ;{ }^{* * *} P<0.001$. 
of milk energy output (dMEO, MJ/d) of both MEL were significantly lower than those observable in bovine herds (where this factor was expressed as herd productivity level; Stocco et al., 2017), but this was expected, considering the different species and the environment in which the goats are reared. It is important to remember that all the 21 farms studied here were characterized by the extensive management system, and the MEL classification allowed for a balanced division of Central-East and South-West farms. Even though dMEO is based on daily production of fat, protein, and lactose, no difference in milk composition was observed between the 2 MEL categories.

In previous studies, goat milk composition was slightly influenced by the type of farming system (Van Quackebeke et al., 1996), and the effect of feeding type has not been extensively studied in goats. However, Min et al. (2005) reported that dMY, milk fat, protein, and lactose were the lowest for goats grazing only on mixed vegetative forages (no concentrate) compared with those fed with 0.33 or $0.66 \mathrm{~kg}$ of concentrate per kilogram of milk (high-producing goats: $>1.5 \mathrm{~kg}$ of milk/d). Inglingstad et al. (2014) studied the effect of diet (cultivated vs. rangeland pasture, and high vs. low hay quality) on goat milk composition and coagulation properties and evidenced that, in general, milk from goats on pasture was richer in protein and casein compared with milk from goats fed with hay, so that RCT was significantly shorter in milk from goats fed with hay.

Results of the present study are different than those from dairy cows, in which the effect of herd productivity level was larger (Stocco et al., 2017, 2018a). The faster coagulation and the higher \%REC samples from goats reared in high-MEL farms could be related to the protein and casein genetic variants, rather than to their overall quantities, as no differences in milk composition have been observed between MEL farm categories. Two recent studies have accurately evidenced that the composition of goat milk can directly influence coagulation and cheese-making ability (Stocco et al., 2018b; Pazzola et al., 2019), but we also find some genes of particular interest (whey protein genes), especially in the Sarda breed, that influence renneting properties (Dettori et al., 2015a,b). Probably, these genes also have an important influence on cheese yields and on the efficiency of recovery of nutrients in curd, but this is still under investigation.

\section{Effect of Geographic Area}

The idea to test the effect of geographic area was linked to the crossbreeding phenomenon that has oc- curred with greater intensity in the South-West area of the island (Vacca et al., 2016), where farmers have frequently crossed their goats with Maltese bucks (an Italian breed from Sicily), as previously mentioned. This has led to recombination of the original genetic traits of both Sarda and Maltese goats. Several breeds have been imported to improve the animals' productive performance, and the best results have been obtained with Maltese bucks, combining their high MY and suitability for grazing the extensive Sardinian scrublands (Usai et al., 2006). Crossing autochthonous goats with specialized dairy breeds ensures high milk production, although imported animals are seldom adaptable to local climate conditions (Lu and Miller, 2019). However, when farmers rear high-yielding goats imported from areas geographically similar to those of local breeds, traits from both types are successfully absorbed from the crossbred animals (e.g., Majorera goats; Capote, 2017). On the other hand, if the nutritional requirements for milk production are not satisfied, the use of high-yielding goats becomes ineffective (Capote, 2002). A recent study has evidenced that coagulation, curdfirming, and syneresis traits are better in Maltese goats compared with Alpine breeds (Pazzola et al., 2018), although the composition of milk from Maltese is much more similar to that from Alpine goats and much worse compared with the Sarda. Indeed, milk from the Sarda is characterized by superior quality and technological aptitude compared with other dairy goat breeds (e.g., Saanen, Camosciata delle Alpi, Murciano-Granadina, Maltese; Vacca et al., 2018a). But the higher \%CY and \%REC traits from the Sarda breed can only partially counterbalance the higher MY characterizing Maltese goats (Vacca et al., 2018b). Thus, increase of milk production was the main objective of farmers who crossed their Sardinian goats with Maltese bucks, even though descriptions of the characteristics of milk quality, coagulation process, and cheese-making ability of these animals have not been reported yet. In bovines it is acknowledged that crossbred cows produce lower quantities (in $\mathrm{kg}$ ) of milk, fat, and protein but higher concentrations (\%) of these components in milk, compared with purebred cows. Thus, generally, crossbreeding is considered a viable method for improving the technological properties of milk, particularly the coagulation time and curd-firming process, but also other important traits related to fertility and longevity (Malchiodi et al., 2014). The shorter $\mathrm{k}_{20}$ recorded in goats from the South-West area could be related to the lower content of fat and lactose in milk (Stocco et al., 2019a,b), but this could not concurrently explain the higher curd firmness value. Possibly, differences in the proportions of milk protein fractions, in the frequency 
of their genetic variants, or both (due to crossbreeding recombination), could explain the difference in the $\mathrm{a}_{30}$ trait between the 2 areas. It is also possible that these differences in milk characteristics result from the different altitudes at which farms were located and, therefore, to different pasture compositions. In fact, many farms in the Central-East area were located in the mountains, where trees prevail over shrubs.

Goats reared in the 2 areas produced the same \%CY but with different proportions of solids and water: $\% \mathrm{CY}_{\text {SOLIDS }}$ was greater in the Central-East area (perhaps deriving from the higher total solids in milk). Daily fresh cheese yield was higher in the South-West area, but it was higher because of the higher value of water retained in the curd $\left(\mathrm{dCY}_{\text {WATER }}\right)$ and not because of the higher total solids $\left(\mathrm{dCY}_{\text {SOLIDS }}\right.$ were similar between areas). High water content in the curd increases \%CY values, but an excess of water could not be considered a positive finding, as, generally, high moisture content leads to a worsening of cheese quality during ripening, with a depreciation of the final product (Martin et al., 1997).

\section{Effect of DIM}

Many studies in the literature have investigated the effects of goat DIM on composition (Zeng et al., 1997; Fekadu et al., 2005; Idamokoro et al., 2017), but less is known about the effect on coagulation and cheesemaking traits. Zeng et al. (1997) reported that concentrations of milk fat, protein, solids-nonfat, and total solids from Alpine goats were higher in the first 30 DIM and then declined slightly and remained constant until drying off. Those authors also reported that daily milk production decreased gradually, in agreement with our results, together with the daily cheese production. Zeng et al. (1997) observed marked daily variations of goat SCC. In the present study, the possibility of dividing the lactation period into many classes allowed a better representation of the trends of each component, although they were sometimes erratic. The division into early, middle, and late lactation can lead to curvilinear or cubic trends becoming linear, as evidenced by Mioč et al. (2008) and Idamokoro et al. (2017) for goat milk composition. However, Mestawet et al. (2012), studying the variation of milk composition during early, middle, and late lactation of 4 goat breeds in Ethiopia, reported quadratic trends for fat, protein, and total solids, with the lowest values at middle lactation and a peak in late lactation.

In dairy cows, both traditional MCP and modeled $\mathrm{CF}_{\mathrm{t}}$ parameters are strongly influenced by DIM, contrary to the results of the present study, and this could be explained by the much more linear trend of each milk component in cows (Stocco et al., 2017). As a consequence of this, bovine cheese-making traits (especially $\% \mathrm{CY}$ traits) greatly change (linear increase) during lactation (Stocco et al., 2018a), and in sheep the same pattern for these traits has also been observed (CipolatGotet et al., 2016b). However, besides the differences among species, it is important to remember that the different division of DIM in classes among studies could led to very different results, especially within species.

\section{Effect of Parity}

No information is available on the effects of many orders of parity on the coagulation and cheese-making traits of goats. Rather, some studies are focused on the variability of milk composition (Mioč et al., 2008; Lôbo et al., 2017), SCC, and bacterial count (Zeng and Escobar, 1995) of goats with different orders of parity. Mioč et al. (2008) did not observe significant changes across parities for milk fat and lactose, but found a decreased protein content moving from the first to the fifth or greater parity. Zeng and Escobar (1995) did not find any significant effect of parity on goat milk composition, SCC, and bacterial count, but only on MY. That difference could be attributable to the low number of parities considered (from first to third parity). On the contrary, results by Lôbo et al. (2017), regarding the effects of 7 orders of parity of dairy goats in Brazil, have evidenced the decrease of milk components across parities and, in agreement with our results, the increase of SCS from the first to the seventh parity. Those authors suggested that the increase of somatic cells could be related to the growing susceptibility of the goats to mastitis (especially of subclinical type) over the different lactations. That result could be further supported by the greater difference in LBC found in the present study between younger (lower) and older goats (higher). The differences of milk composition found among parities were not followed by great differences in coagulation traits, as only higher curd firmness $\left(\mathrm{a}_{30}\right)$ was observed in younger goats compared with the older ones. This finding could be explained by the higher fat content and lower SCS and LBC in milk from the first compared with the latter (Stocco et al., 2018b). Among \%CY traits, only \% $\mathrm{CY}_{\text {SOLIDS }}$ was affected by parity, with higher values in goats at first and second parities compared with goats at the third parity or greater. This result could be attributable to the different composition of milk in younger goats, as it is acknowledged that milk composition affects \% CY and \%REC traits (Pazzola et al., 2019). Indeed, recovery of nutrients was higher in younger goats, except for $\% \mathrm{REC}_{\text {SOLIDS }}$, 
whereas the lowest \%REC values were recorded from goats in the fifth parity or greater. As expected, daily cheese productions were lower in younger goats, and this was mainly due to the lower MY. In sheep, younger ewes are characterized by better MCP, compared with older ones, and by higher \% REC $\mathrm{SOLIDS}_{\text {(Cipolat-Gotet }}$ et al., 2016b).

\section{CONCLUSIONS}

This study provided a detailed characterization of the Sarda goat breed in terms of milk quality, technological characteristics, cheese yield, and milk nutrients recovery in the curd. The favorable qualitative and technological characteristics of milk from Sarda suggests that this breed has a high potential for cheese production that needs to be preserved. The characterization of the Sarda breed provided by this study could be a key point for its preservation and enhancement, and could be of great interest for the goat dairy sector. The collection of a wide range of phenotypes at the individual animal level is fundamental for the characterization of local populations and can be used to guarantee breed conservation, persistence of traditional farming system, and increase the farmers' profit.

\section{ACKNOWLEDGMENTS}

This research was supported by the Regional Government of Sardinia (Progetto Strategico Sulcis; CUP J73C17000070007, Cagliari, Italy). The authors thank the farmers for giving access to their flocks; the APAs (Provincial Farmers Associations) of Cagliari and Nuoro (Italy), and the firms Società Agricola is Crabaxius (Fluminimaggiore, Italy), Azienda Agricola Murgia Antonello (Sant'Anna Arresi, Italy), Latteria Sociale Santadi (Santadi, Italy), Azienda Agricola F.lli Secci s.s. (Iglesias, Italy), and Agricola Allevatori Tallaroga, Soc. Coop. (Villamassargia, Italy) for their support in sample collection; and ARA Sardegna (Regional Farmers Association of Sardinia, Cagliari, Italy) for support in chemical milk analysis. The authors have not stated any conflicts of interest.

\section{REFERENCES}

Bittante, G. 2011. Modeling rennet coagulation time and curd firmness of milk. J. Dairy Sci. 94:5821-5832. https://doi.org/10.3168/ jds.2011-4514.

Bittante, G., M. Penasa, and A. Cecchinato. 2012. Invited review: Genetics and modeling of milk coagulation properties. J. Dairy Sci. 95:6843-6870. https://doi.org/10.3168/jds.2012-5507.

Boyazoglu, J., I. Hatziminaoglou, and P. Morand-Fehr. 2005. The role of the goat in society: Past, present and perspectives for the future. Small Rumin. Res. 60:13-23. https://doi.org/10.1016/j .smallrumres.2005.06.003.
Capote, J. 2002. Sistema de explotación caprina en zonas áridas. Pages 95-100 in Actas de las XXVII Jornadas Científicas y VI Internacionales de la SEOC.

Capote, J. 2017. Introductory Chapter: Goats in Arid and Mountain Areas In Sustainable Goat Production in Adverse Environments: Volume II. J. Simoes and C. Gutierrez, ed. Springer, Cham, Switzerland.

Čermák, B., V. Král, J. Frelich, L. Boháčová, B. Vondrášková, J. Spička, E. Samková, M. Podsedníček, A. Węglarz, J. Makulska, and P. Zapletal. 2013. Quality of goat pasture in less-favoured areas (LFA) of the Czech Republic and its effect on fatty acid content of goat milk and cheese. Anim. Sci. Pap. Rep. 31:331-346.

Cipolat-Gotet, C., A. Cecchinato, M. De Marchi, M. Penasa, and G. Bittante. 2012. Comparison between mechanical and near-infrared methods for assessing coagulation properties of bovine milk. J. Dairy Sci. 95:6806-6819. https://doi.org/10.3168/jds.2012-5551.

Cipolat-Gotet, C., A. Cecchinato, M. Pazzola, M. L. Dettori, G. Bittante, and G. M. Vacca. 2016b. Potential influence of herd and animal factors on the yield of cheese and recovery of components from Sarda sheep milk, as determined by a laboratory bench-top model cheese-making. Int. Dairy J. 63:8-17. https://doi.org/10 .1016/j.idairyj.2016.07.013.

Cipolat-Gotet, C., A. Cecchinato, G. Stocco, and G. Bittante. 2016a. The 9-MilCA method as a rapid, partly automated protocol for simultaneously recording milk coagulation, curd firming, syneresis, cheese yield, and curd nutrients recovery or whey loss. J. Dairy Sci. 99:1065-1082. https://doi.org/10.3168/jds.2015-9734.

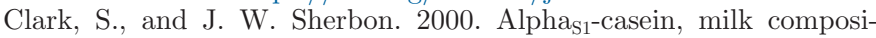
tion and coagulation properties of goat milk. Small Rumin. Res. 38:123-134. https://doi.org/10.1016/S0921-4488(00)00154-1.

Dal Zotto, R., M. De Marchi, A. Cecchinato, M. Penasa, M. Cassandro, P. Carnier, L. Gallo, and G. Bittante. 2008. Reproducibility and repeatability of measures of milk coagulation properties and predictive ability of mid-infrared reflectance spectroscopy. J. Dairy Sci. 91:4103-4112. https://doi.org/10.3168/jds.2007-0772.

Damián, J. P., I. Sacchi, S. Reginensi, D. De Lima, and J. Bermudez. 2008. Cheese yield, casein fractions and major components of milk of Saanen and Anglo-Nubian dairy goats. Arq. Bras. Med. Vet. Zootec. 60:1564-1569. https://doi.org/10.1590/S0102 -09352008000600040 .

Dettori, M. L., M. Pazzola, P. Paschino, M. G. Pira, and G. M. Vacca. 2015a. Variability of the caprine whey protein genes and their association with milk yield, composition and renneting properties in the Sarda breed. 1. The $L A L B A$ gene. J. Dairy Res. 82:434-441. https://doi.org/10.1017/S0022029915000461.

Dettori, M. L., M. Pazzola, E. Pira, O. Puggioni, and G. M. Vacca. 2015b. Variability of the caprine whey protein genes and their association with milk yield, composition and renneting properties in the Sarda breed: 2. The $B L G$ gene. J. Dairy Res. 82:442-448. https://doi.org/10.1017/S0022029915000473.

Di Trana, A., L. Sepe, P. Di Gregorio, M. A. Di Napoli, D. Giorgio, A. R. Caputa, and S. Claps. 2015. The role of local sheep and goat breeds and their products as a tool for sustainability and safeguard of the Mediterranean environment. Pages 77-112 in The Sustainability of Agro-Food and Natural Resources Systems in the Mediterranean Basin. Springer International Publishing AG, Cham, Switzerland.

Dubeuf, J. P. 2011. The social and environmental challenges faced by goat and small livestock local activities: Present contribution of research development and stakes for the future. Small Rumin. Res. 98:3-8. https://doi.org/10.1016/j.smallrumres.2011.03.008.

FAO (Food and Agriculture Organization of the United Nations). 2014. DAD-IS (Domestic Animal Diversity Information System). Statistical Database of the Food and Agriculture Organization of the United Nations. Accessed April 5, 2019. http://www.fao.org/ dad-is/browse-by-country-and-species/en/.

Fekadu, B., K. Soryal, S. Zeng, D. Van Hekken, B. Bah, and M. Villaquiran. 2005. Changes in goat milk composition during lactation and their effect on yield and quality of hard and semi-hard cheeses. Small Rumin. Res. 59:55-63. https://doi.org/10.1016/j .smallrumres.2004.12.003. 
Ferragina, A., C. Cipolat-Gotet, A. Cecchinato, M. Pazzola, M. L. Dettori, G. M. Vacca, and G. Bittante. 2017. Prediction and repeatability of milk coagulation properties and curd-firming modeling parameters of ovine milk using Fourier-transform infrared spectroscopy and Bayesian models. J. Dairy Sci. 100:3526-3538. https://doi.org/10.3168/jds.2016-12226.

Guo, M., Y. W. Park, P. H. Dixon, J. A. Gilmore, and P. S. Kindstedt. 2004. Relationship between the yield of cheese (Chevre) and chemical composition of goat milk. Small Rumin. Res. 52:103-107. https://doi.org/10.1016/S0921-4488(03)00247-5.

Idamokoro, E., V. Muchenje, and P. Masika. 2017. Yield and milk composition at different stages of lactation from a small herd of Nguni, Boer, and non-descript goats raised in an extensive production system. Sustainability 9:1000. https://doi.org/10.3390/ su9061000.

Inglingstad, R. A., H. Steinshamn, B. S. Dagnachew, B. Valenti, A. Criscione, E. O. Rukke, T. G. Devold, S. B. Skeie, and G. E. Vegarud. 2014. Grazing season and forage type influence goat milk composition and rennet coagulation properties. J. Dairy Sci. 97:3800-3814. https://doi.org/10.3168/jds.2013-7542.

ISO-IDF (International Organization for Standardization and International Dairy Federation). 2004. Milk: Quantitative determination of bacteriological quality - Guidance for establishing and verifying a conversion relationship between routine method results and anchor method results. International Standard ISO 21187 and IDF 196:2004. ISO, Geneva, Switzerland, and IDF, Brussels, Belgium.

ISO-IDF (International Organization for Standardization and International Dairy Federation). 2010. Milk and liquid milk products: Determination of total solids content. International Standard ISO 6731 and IDF 21:2010a. ISO, Geneva, Switzerland, and IDF, Brussels, Belgium.

ISO-IDF (International Organization for Standardization and International Dairy Federation). 2013. Milk and liquid milk products: Determination of fat, protein, casein, lactose and $\mathrm{pH}$ content. International Standard ISO 9622 and IDF 141:2013. ISO, Geneva, Switzerland, and IDF, Brussels, Belgium.

Kouniba, A., M. Berrada, and A. El Marakchi. 2007. Etude comparative de la composition chimique du lait de chèvre de la race locale Marocaine et la race alpine et évaluation de leur aptitude fromagère. Rev. Med. Vet. 158:152-160.

Lôbo, A. M. B. O., R. N. B. Lôbo, O. Facó, V. Souza, A. A. C. Alves, A. C. Costa, and M. A. M. Albuquerque. 2017. Characterization of milk production and composition of four exotic goat breeds in Brazil. Small Rumin. Res. 153:9-16. https://doi.org/10.1016/j .smallrumres.2017.05.005.

Lu, C. D., and B. A. Miller. 2019. Current status, challenges and prospects for dairy goat production in the Americas. Asian-Australas. J. Anim. Sci. 32:1244-1255. https://doi.org/10.5713/ajas.19.0256.

Malchiodi, F., A. Cecchinato, M. Penasa, C. Cipolat-Gotet, and G. Bittante. 2014. Milk quality, coagulation properties, and curd firmness modeling of purebred Holsteins and first- and secondgeneration crossbred cows from Swedish Red, Montbéliarde, and Brown Swiss bulls. J. Dairy Sci. 97:4530-4541. https://doi.org/10 $.3168 /$ jds.2013-7868.

Martin, B., J.-F. Chamba, J.-B. Coulon, and E. Perreard. 1997. Effect of milk chemical composition and clotting characteristics on chemical and sensory properties of Reblochon de Savoie cheese. J. Dairy Res. 64:157-162. https://doi.org/10.1017/S0022029996001975.

Mestawet, T. A., A. Girma, T. Ådnøy, T. G. Devold, J. A. Narvhus, and G. E. Vegarud. 2012. Milk production, composition and variation at different lactation stages of four goat breeds in Ethiopia. Small Rumin. Res. 105:176-181. https://doi.org/10.1016/j smallrumres.2011.11.014.

Min, B. R., S. P. Hart, T. Sahlu, and L. D. Satter. 2005. The effect of diets on milk production and composition, and on lactation curves in pastured dairy goats. J. Dairy Sci. 88:2604-2615. https://doi .org/10.3168/jds.S0022-0302(05)72937-4.

Mioč, B., Z. Prpić, I. Vnučec, Z. Barać, V. Sušić, D. Samaržija, and V. Pavić. 2008. Factors affecting goat milk yield and composition. Mljekarstvo 58:305-313.
Moioli, B., M. D'Andrea, and F. Pilla. 2007. Candidate genes affecting sheep and goat milk quality. Small Rumin. Res. 68:179-192. https: //doi.org/10.1016/j.smallrumres.2006.09.008.

Nájera, A. I., M. de Renobales, and L. I. R. Barron. 2003. Effects of $\mathrm{pH}$, temperature, $\mathrm{CaCl} 2$ and enzyme concentrations on the rennet clotting properties of milk: A multifactorial study. Food Chem. 80:345-352. https://doi.org/10.1016/S0308-8146(02)00270-4.

NRC. 2001. Nutrient Requirements of Dairy Cattle. 7 th rev. ed. Natl. Acad. Press, Washington, DC.

Pazzola, M., M. L. Dettori, E. Pira, A. Noce, P. Paschino, and G. M. Vacca. 2014a. Effect of polymorphisms at the casein gene cluster on milk renneting properties of the Sarda goat. Small Rumin. Res. 117:124-130. https://doi.org/10.1016/j.smallrumres.2013.12.004.

Pazzola, M., M. L. Dettori, and G. M. Vacca. 2017. The Sarda goat, A resource for the extensive exploitation in the Mediterranean environment. In Sustainable Goat Production in Adverse Environments: Volume II. J. Simões and C. Gutiérrez, ed. Springer, Cham, Switzerland.

Pazzola, M., G. Stocco, M. L. Dettori, G. Bittante, and G. M. Vacca. 2019. Effect of goat milk composition on cheesemaking traits and daily cheese production. J. Dairy Sci. 102:3947-3955. https://doi .org/10.3168/jds.2018-15397.

Pazzola, M., G. Stocco, P. Paschino, M. L. Dettori, C. Cipolat-Gotet, G. Bittante, and G. M. Vacca. 2018. Modeling of coagulation, curd firming, and syneresis of goat milk from 6 breeds. J. Dairy Sci. 101:7027-7039. https://doi.org/10.3168/jds.2018-14397.

Shook, G. E. 1993. Genetic improvement of mastitis through selection on somatic cell count. Vet. Clin. North Am. Food Anim. Pract. 9:563-577. https://doi.org/10.1016/S0749-0720(15)30622-8.

Silanikove, N. 2000. The physiological basis of adaptation in goats to harsh environments. Small Rumin. Res. 35:181-193. https://doi .org/10.1016/S0921-4488(99)00096-6.

Sponenberg, D. P., A. Martin, A. Couch, and J. Beranger. 2019. Conservation strategies for local breed biodiversity. Diversity (Basel) 11:177-191. https://doi.org/10.3390/d11100177.

Stocco, G., C. Cipolat-Gotet, T. Bobbo, A. Cecchinato, and G. Bittante. 2017. Breed of cow and herd productivity affect milk composition and modeling of coagulation, curd firming and syneresis. J. Dairy Sci. 100:129-145. https://doi.org/10.3168/jds.2016-11662. Stocco, G., C. Cipolat-Gotet, V. Gasparotto, A. Cecchinato, and G. Bittante. 2018a. Breed of cow and herd productivity affect milk nutrient recovery in curd, and cheese yield, efficiency and daily production. Animal 12:434-444. https://doi.org/10.1017/ S1751731117001471.

Stocco, G., M. Pazzola, M. L. Dettori, P. Paschino, G. Bittante, and G. M. Vacca. 2018b. Effect of composition on coagulation, curdfirming and syneresis of goat milk. J. Dairy Sci. 101:9693-9702. https://doi.org/10.3168/jds.2018-15027.

Stocco, G., M. Pazzola, M. L. Dettori, P. Paschino, A. Summer, C. Cipolat-Gotet, and G. M. Vacca. 2019a. Effects of indirect indicators of udder health on nutrient recovery and cheese yield traits in goat milk. J. Dairy Sci. 102:8648-8657. https://doi.org/10.3168/ jds.2019-16369.

Stocco, G., M. Pazzola, M. L. Dettori, C. Cipolat-Gotet, A. Summer, and G. M. Vacca. 2019b. Variation in caprine milk composition and coagulation as affected by udder health indicators. Int. Dairy J. 98:9-16. https://doi.org/10.1016/j.idairyj.2019.06.005.

Tyrisevä, A.-M., T. Ikonen, and M. Ojala. 2003. Repeatability estimates for milk coagulation traits and non-coagulation of milk in Finnish Ayrshire cows. J. Dairy Res. 70:91-98. https://doi.org/10 $.1017 /$ S0022029902005939.

Usai, M. G., S. Casu, G. Molle, M. Decandia, S. Ligios, and A. Carta. 2006. Using cluster analysis to characterize the goat farming system in Sardinia. Livest. Sci. 104:63-76. https://doi.org/10.1016/j .livsci.2006.03.013.

Vacca, G. M., M. L. Dettori, V. Carcangiu, A. M. Rocchigiani, and M. Pazzola. 2010. Relationships between milk characteristics and somatic cell score in milk from primiparous browsing goats. Anim. Sci. J. 81:594-599. https://doi.org/10.1111/j.1740-0929.2010 .00774.x. 
Vacca, G. M., P. Paschino, M. L. Dettori, M. Bergamaschi, C. CipolatGotet, G. Bittante, and M. Pazzola. 2016. Environmental, morphological and productive characterization of Sardinian goats and use of latent explanatory factors for population analysis. J. Anim. Sci. 94:3947-3957. https://doi.org/10.2527/jas.2016-0542.

Vacca, G. M., G. Stocco, M. L. Dettori, E. Pira, G. Bittante, and M. Pazzola. 2018a. Milk yield, quality and coagulation properties of 6 breeds of goats: Environmental and individual variability. J. Dairy Sci. 101:7236-7247. https://doi.org/10.3168/jds.2017-14111.

Vacca, G. M., G. Stocco, M. L. Dettori, A. Summer, C. Cipolat-Gotet, G. Bittante, and M. Pazzola. 2018b. Cheese yield, cheese-making efficiency, and daily production of 6 breeds of goats. J. Dairy Sci. 101:7817-7832. https://doi.org/10.3168/jds.2018-14450.

Van Quackebeke, E., Y. Lefrileux, A. Pommaret, and C. Audic. 1996. Comparaison de deux systèmes d'alimentation des chèvres laitières. Renc. Rech. Rum. 3:289-292.

Zeng, S. S., and E. N. Escobar. 1995. Effect of parity and milk production on somatic cell count, standard plate count and composition of goat milk. Small Rumin. Res. 17:269-274. https://doi.org/10 .1016/0921-4488(95)00658-8.

Zeng, S. S., E. N. Escobar, and T. Popham. 1997. Daily variations in somatic cell count, composition, and production of Alpine goat milk. Small Rumin. Res. 26:253-260. https://doi.org/10.1016/ S0921-4488(96)01002-4.

\section{ORCIDS}

Pietro Paschino 누 https://orcid.org/0000-0002-2302-9792

Giorgia Stocco ๑ https://orcid.org/0000-0002-6786-9806

Maria L. Dettori (ㄴ https://orcid.org/0000-0001-5413-0335

Michele Pazzola (ํ) https://orcid.org/0000-0001-5685-0416

Maria L. Marongiu (ํ https://orcid.org/0000-0003-4791-0514

Claudio Cipolat-Gotet 으 https://orcid.org/0000-0002-2318-4231

Giuseppe M. Vacca @ https://orcid.org/0000-0003-3110-5211 